\title{
The Truman Show, Into The Wild ve Hollywood Sinemasının Sahte Eleştirelliği
}

\author{
Erdem İlic*
}

Özet

Başta ticari Amerikan sineması olmak üzere anaakım sinemanın önde gelen yapımlarmın mevcut egemen ideolojik ve politik iklimin sözcüsü ve yeniden üreticisi olduğuna dair yaygın bir görüş vardır. Buna rağmen anaakım sinema ürünü olmasına karşın kendisini eleştirel bir konuma yerleştiren örneklerin var olduğu da sıklıkla öne sürülür. The Truman Show ve Into the Wild filmleri de kurduğu çatışma ilişkileri ve öykülemesi ile anaakım sinemanın eleştirel örneklerinden olarak tanımlanır. Bu çalışma söz konusu iki filmin çatışma ilişkilerinden yola çıkarak semantik bir ilişkiye sahip olduğunu öne sürecek ve filmlerin ana fikirlerinde ortaya atılan etik ve ideolojik değerleri, kapitalizmin dönüşümü ile ilişkili olarak değerlendirecektir.

Yirminci yüzyılın son çeyreğinden itibaren çağdaş kapitalizmin bir dönüşüm süreci içine girdiği yönünde çeşitli tezler öne sürülmektedir. Bu çalışmada söz konusu dönüşüm Michel Foucault'nun "disiplin toplumları" kavramı ve bu toplumsal örgütlenmelerin yerini alan neoliberal yönetimsellik bağlamlarında ele alınarak seçilen filmlerin öykülemeleri bu tartışmaya denk düşecek şekilde değerlendirilecektir. Böylece filmlerin eleştirel argümanlarn ile kapitalizmin dönüşümü arasında bir karşılaştırma süreci yürütülecektir. Dönüşüm çerçevesinde kapitalizmin terk ettiği kurumlar ve üretilen yeni öznellik kipi dikkate alındığında The Truman Show ve Into the Wild filmlerinin eleştirel olmadığı, egemen politik iklimle uyumlu bir öykülemeyi ve çatışma dinamiklerini barındırdığı öne sürülecektir.

Anahtar Kelimeler: Into The Wild, The Truman Show, disiplin toplumlar, neoliberalizm

ORCID ID : https:/ / orcid.org/0000-0003-1737-0254

E-mail : ilicerdem@gmail.com

DOI: 10.31122/Sinefilozofi.634907

Geliş Tarihi - Recieved: 15.10 .2019

Kabul Tarihi - Accepted: 15.12.2019 


\title{
The Truman Show, Into The Wild and The Pseudo Opposition of Hollywood
}

\author{
Erdem İlic*
}

\begin{abstract}
There is a common belief that the major products of mainstream cinema, particularly commercial American cinema, are the producers of the current dominant ideological and political climate. However it is also frequently stated that there are some examples placing themselves in a critical position despite their mainstream character. The movies, The Truman Show and Into the Wild are considered as critical examples of mainstream cinema due to their conflict relations and narratives. This study will suggest that those two mentioned films have a semantic relationship based on their conflict relationships and will evaluate the ethical and ideological values that derive from the main ideas of the films within their relationship with the transformation of capitalism.

Since the last quarter of the twentieth century, various arguments have been proposed that contemporary capitalism has entered a process of transformation. In this study that transformation will be discussed in the context of Michel Foucault's concept of "disciplinary societies" and the neoliberal govermentality that replace these social organizations and the narratives of the selected films will be evaluated in a way that corresponds to this discussion. In this context the critical arguments of the films will be compared to the transformation of capitalism. Considering the institutions that capitalism abondon and the new subjectivity that is produced; it will be claimed that the movies The Truman Show and Into the Wild are not critical, contrarily they contain a narrative and dynamics of conflict that are coherent to the dominant political climate.
\end{abstract}

Keywords: Into The Wild, The Truman Show, disciplinary societies, neoliberalism

ORCID ID : https:/ / orcid.org/0000-0003-1737-0254

E-mail : ilicerdem@gmail.com

DOI: 10.31122/Sinefilozofi.634907

Geliş Tarihi - Recieved: 15.10 .2019

Kabul Tarihi - Accepted: 15.12.2019 


\section{Giriş}

Başta Amerikan ticari sineması olmak üzere Dünya'nın önde gelen anaakım sinemalarının belli başlı örnekleri, döneminin egemen iktisadi, politik ve ideolojik söylem ve uygulamalarının sinematografik bir sözcüsü ve retorik üreticisi olagelmiştir. Michael Ryan ve Douglas Kellner Politik Kamera adlı kitaplarında dönemsel olarak "Hollywood sinemasının, oluşmakta olan muhafazakar hareketlenmeyi, aileden orduya ve ekonomik politikaya kadar birçok cephede fiilen desteklemekte" (1997: 13) olduğuna dikkat çeker. Ryan ve Kellner bazı eleştirmenlerin, Hollywood'un egemen kurumları, ideolojileri ve değerleri meşrulaştırmanın bir aracı olarak işlev gördüğü yönündeki savlarını hatırlatarak bu görüşü tartışmaya açar. Kültür endüstrilerinin önemli bir parçası olan ana akım sinema ile egemen kültürel ve ideolojik değerler arasında her zaman mutlak bir paralellik olup olmadığ ${ }_{1}$ konusu gerçekten de tartışmaya açıktır. Hollywood sinemasının bazı örneklerinin çeşitli toplumsal hareketlerin etkisinde kalarak "Amerikan kurum ve değerlerine eleştirel yaklaşımlar" (1997: 43) getirdiğini yine Ryan ve Kellner vurgular.

Öykülemesi ve öne sürdüğü anafikirleri çerçevesinde kendisini eleştirel bir konuma yerleştiren veya eleştirmenlerce bu tür bir değer atfedilen Hollywood filmleri her dönem karşımıza çıkmaktadır. Bu çalışmada ise gerek öyküsü içinde öne sürdüğü tartışmalar, gerekse çeşitli popüler ve akademik yorumlar tarafından bu türden bir eleştirel konuma yerleştirilen iki film, The Truman Show (Truman Show, Peter Weir, 1998) ve Into The Wild (Özgürlük Yolu, 2007, Sean Penn) egemen ekonomi politiğin değerleri ile karşılaştırmalı olarak incelenecektir. Bu seçimdeki temel sebep ise söz konusu iki filmin, kapitalizmin, başta Batı toplumları içinde gerçekleştirdiği dönüşümle ilişkili olarak çözümlenebilecek bir malzeme sunmasıdır. The Truman Show'da karakterin yaşadığı çatışmalar Sanayi Dönemi ve disiplin toplumları paradigmaları ile bu paradigmaların tarihsel krizi ileilişkili; Into The Wild ise dönüşümle birlikte kapitalizmin kurmakta olduğu yeni uzlaşı, değer, kurumsal örgüt modelleri ile karşılaştırmalı olarak incelenecektir. Her iki filmde de karakterlerin serüvenleri ile etik tercihleri bağlaminda semantik bir ilişki bulunmaktadır. Burada yürütülmeye çalışılan, filmler özelinde herhangi bir yönüyle metaforik olmayan bir analizdir. Her iki film de Michel Foucault'nun disiplin toplumları olarak adlandırdığı tarihsel analizi ile bu toplumların krizinin ardından gelen yeni yönetimsellik modelleri ile ilişkili olarak incelenmiştir.

\section{Çatışmanın Hedefindeki Disiplin Toplumları}

The Truman Show ve Into The Wild filmlerinin gerek sinematografik olarak, gerekse öyküleme içinde öne sürdüğü çatışmalardan doğan tartışmanın eleştirel boyutu, Batı toplumlarında çağdaş kapitalizmin girdiği dönemsel kriz ve dönüşüm bağlamında değerlendirilmek istenirse, Michel Foucault'nun tarihsel analizi ve bu analizden hareketle işaret ettiği dönüşümler uygun bir teorik art alan oluşturur. Michel Foucault, kapitalizmin doğuşunun ardından ve Sanayi Devrimi ile birlikte ortaya çıkan kapsayıcı düzeni "disiplin toplumları" olarak adlandırmıştı. Düşünür, yirminci yüzyılın ikinci yarısı ile birlikte bu toplumsal yapılanmadan uzaklaşıldığını görmekle birlikte, Klasik Çağ olarak adlandırdığı bu dönemin kapsamlı bir analizini yapmıştır. Foucault'nun çalışmasında karşılaştı̆̆ı ortak imge, yaygınlaştırılmış bir kapatma uygulaması ile devreye sokulan iktidar dispositifleri olmuştur. 
Dispositif kavramını, "söylemler, kurumlar, mimari biçimler, düzenleyici kararlar, yasalar, idari önlemler, bilimsel sözceler, felsefi, ahlaki ve hayırseverce önermelerden" (2005, 119) oluşan ilişkilerin ağı olarak tanımlayan Foucault, kapatma uygulamalarını öncelikli olarak beden üzerinde işleyen anatomo-politik, ardından nüfus ve oranlarına yönelik biyo-politik iktidar kutuplarının tekniklerinden biri olarak tanımlamıştır. Bu yaygın tekniğin sonucunda Batı toplumları on altıncı ve yirminci yüzyıllar arasında kapatılmıştır. İngiltere, Almanya ve Paris'te kurulan atölyeler (workhouse), sslahhaneler ve Genel Hastaneler bir taraftan yoksul hasta ve suçluları kapatıp diğer taraftan onları çalıştırmak için dönemin monarşik iktidarlarının, önce kendi sınırları içinde sonra Avrupa'da hızla yaygınlaştırdığı kurumlar olur. Foucault, Genel Hastaneyi "monarşik ve burjuva bir düzenin bir yürütme makamı" (2015: 92) olarak tanımlar. Tüm kapatma kurumları çalışmayı bir toplumsal görev olarak uygulamanın aracı kılınır: "kapatılanlar çalışmak zorundadırlar. Emeklerinin tam değeri hesaplanmakta ve bunun dörtte biri onlara verilmektedir" (2015: 117). Kapatma uygulaması on sekiz ve on dokuzuncu yüzyıl boyunca islahevleri ve atölyeler gibi öncü örneklerinden fabrika, hapishane, hastane, okul gibi kurumlara dönüşür. Buralarda uygulanan teknikler yalnızca kapatmak ve çalıştırmak ile yetinmeyen, aynı zamanda incelikli bir gözetleme ve denetim mekaniklerini her an devrede tutarak anatomo-politik ve biyo-politik iktidarı hem ayrı ayrı bedenler hem de toplumlar üzerinde işletme amacındadır. ${ }^{1}$ Bu iki iktidar kutbunun bir arada biyo-iktidar olarak kavramsallaştıran Foucault, diğer yandan kapatmanın vazgeçilmez olmadığını da en başından beri vurgulamıştır. Gilles Deleuze, buradaki kurumsal örgütlenmelerin analojik modelinin hapishane olduğunu vurgular (2013:187). Gündelik zamanı belirli parçalara ayırarak içeriğini rutinleştirmek, asimetrik tekniklerle gözetleyerek kendilerini disipline etmelerini sağlamak, yalnızca mahkumlar değil; işçiler, hastalar ve öğrenciler için de yürürlüğe konulan uygulamalardir.

Kapatılma ile amaçlanan, Foucault'nun iktidarın nesnesi ve hedefi olarak tanımladığı (2000: 208) beden üzerinde denetim uygulamaktır. Biri diğerini pekiştirecek şekilde yararlı hale gelmek ve itaatkar olmak şeklinde gelişen, duruşu, davranışı, hareketi, süreyi, eklemleri otomat imgesindeki gibi detaylı bir kinetizme tabi kılarak, bedeni tam bir iktidar mekanizmasının içine atan "ayn zamanda bir "iktidar mekaniği" de olan bir "siyasal anatomi" doğmaktadır" (2000: 211). Foucault, bu mekaniği oluşturmak için uygulanan çeşitli teknikleri sıralar. İlki "kapalı bir alanın özelleştirilmesi" (2000: 215) biçiminde tanımladı̆̆ı, tüm kurumlar için şart koşulmaya başlanan bir kapatma biçimidir. Suçlular ve hastalar çalışan toplumu korumak adına kapatılır, ancak bu durum toplumun geri kalanının serbest birakıldığı anlamina gelmez. Okulların giderek daha fazla manastır modelini benimsemesi sağlanarak yatılılık yaygınlaştırılır. Yeni kararnameler ile kışlalar geçmişte olduğundan daha katı bir kapalı tutma aygıtı olarak işler. Dağınık atölyelerden türdeş ve sınırları belirlenmiş manifaktür alanlarına geçilir. Foucault gözlemlenen değişimin "yeni bir denetim tarzı" (2000: 216) olduğunu vurgular. Böylece "üretim güçlerinin yoğunlaşması" (2000: 217) ve emek gücü ile üretim araçları üzerinde egemenlik kurulması sağlanır. Şüphesiz bu türden bir sınır-duvar örme, tek başına "ne sabit, ne vazgeçilmez, ne de yeterlidir" (2000: 217). İçeride en ince ayrıntısına kadar, analitik olarak örgütlenmiş bir mekânla karşılaşırız: "her kişiye kendi yeri, her yere bir kişi" (2000: 217). Mekânın analitik örgütlenmesi ile kimin nerede ve nasıl bulunacağını belirleyerek gözetim altında tutmak mümkündür. Bunun yanında mimari düzenlemeler ile mekânlar da yalnızca çerçeveleyerek gözetim altında tutmakla kalmaz, aynı zamanda yararlı birer mekân olarak tanimlanir. 
Bir kurumun gözetimi diğer kurumların yürütmekle mükellef olduğu denetimlerle dayanışma içindedir. Zaman dakika ve saniye cinsinden, ritmik, düzenli, parçalı biçimiyle uygulanırken, bu zamanın niteliği kesintisiz denetimlerle "bütünsel olarak yararlı" (2000: 229) kılmak adina artırılır.

Zamanın yönetimi yalnızca mesai saatlerindeki dakiklik biçiminde gerçekleşmez. Beden zamanın bir parametre olarak kullanıldığı emirlere uyarlanır. Böylece ortaya bir program çıkar. Bu program "eylemin kendisinin yoğunlaşmasını sağlamaktadır; onun akışını ve safhalarını içeriden denetlemektedir" (2000: 229).

Eylemi unsurlarına bölen kronometrik zaman harekete "bir yön, bir genişlik, bir süre tahsis" (2000: 229) ederek bedene biyo-iktidarın incelikli denetimlerinin nüfuz etmesini sağlar.

Foucault'nun, disiplin toplumları çözümlemesi ile buraya kadar özetlenen iktidar mekaniklerinin her birinin The Truman Show'da ana karakter için kurgulanan ve mücadelesini verdiği hayat üzerinde de uygulandığını söyleyebiliriz. Filmin merkezi ögesini oluşturan devasa stüdyonun esasen bir kapatma kurumu; ana karakter Truman'ın bütün amacının ise, başlangıçta varlığından haberdar olmadığı bu kurumdan kurtulmak olduğunu görürüz. Ana karakterin içine yerleştirildiği koşulların tek muhalifi olan sevdiği kadının, Sylvia'nın sözlerini alıntılayarak vurgulamak gerekirse; "Truman bir hapishanededir". Ancak karakterin hapishanede olmasina sebep olan tek öge, uzak diyarlara gitmesine engel olacak bir kapalı alandan ibaret değildir. Gündelik hayatını kesin tanımlanmış rutinlere sokan aile, iş ve arkadaşlık kurumlarının bağlayıcı ve tekdüze ilişkileri de mahpusluğunun diğer bileşenlerini oluşturur. Foucault'nun ifadelerini hatırlayarak söylemek gerekirse, kapalı alan içeride de örgütlenmiş bir mekândır. Ancak bu örgütlenme yeterince analitik ve incelikli işlemekte zorlandığ1 için içeriden gelen bir kurumsal çöküşün zeminini oluşturacaktır. Televizyon programı doğumundan itibaren Truman'ın bedenini merkezine almıştır, karakterin içinde yaşadığı kapalı alanlar özelleştirilmiştir, gündelik hayatında zaman kronolojik olarak işletilir.

Michel Foucault, klasik çağın hapishane modellerinin "iktidarın otomatik işleyişini sağlayan bilinçli ve sürekli bir görünebilirlik halini yaratmak" (Foucault, 2000: 297) işlevine sahip olan, "panoptikon" adını verdiği bir mimari teknoloji ve asimetrik bir gözetleme diyagramı oluşturmak üzere tasarlandığını bulgulamıştı. Bir kişinin görülmeden tüm mahkumları gözetleyebilmesini, mahkumu da gözetleyene dair herhangi bir bilgiden mahrum bırakarak onun her an gözetlendiğini varsaymasını sağlayan bu sistem hem diğer kapatılma kurumlarında uygulanmaya başlanmış, hem de iletişim teknolojilerinin geldiği aşamalar nedeniyle günümüze kadar farklı türlerini yaratarak varlığını sürdürmüştür. Enformatik teknolojilerinin yardımıyla gözetlemenin eylem ve süreçlere dağıtıldığı “duvarsız, penceresiz, kulesiz ve gardiyansız bir gözetleme sistemi olan" (Poster, 1990: 93) "süper-panoptikon" ve "bakışın sadece doğrulanamaz bir olasılıkta değil sabit ve sürekli bir kesinlikte" (Peters, 1999: 82) olmasını sağlayan "enformasyon-panoptikon" modellerinin yanında, doğrultuyu tersine çevirerek tüm toplumun bir kişiyi gözetlediği “sinoptikon” ve herkesin herkesi gözetlemesini

\footnotetext{
${ }^{1}$ Anatomo-politika ve biyo-politika biyo-iktidarı oluşturan iki kutup olarak çalışır: "Bedenin terbiyesi yeteneklerinin artırılması, güçlerinin ortaya çıkarılması, yararlılığıyla itaatkârlığının koşut gelişmesi, etkili ve ekonomik denetim sistemleriyle bütünleşmesi"ni (2010: 102) sağlayan kutup ilk oluşandır ve Foucault buna "insan bedeninin anatomo-politikası" (2010: 102) adını verir. İkincisi daha geç, on sekizinci yüzyıl ortalarında oluşmuş; "biyolojik süreçlerin dayanağını oluşturan bedeni merkez almıştır: bollaşma, doğum ve ölüm oranları, sağlık düzeyi, yaşam süresi ve bunları etkileyebilecek tüm koşullar önem kazanmıştır" (2010: 102-103). Foucault, düzenleyici denetim yoluyla gerçekleşen bu kutba "nüfusun biyo-politikası" der.
} 
sağlayan "omniopotikon" gibi kavramsallaştırmalar halen çeşitli tartışmaların konusudur.

The Truman Show'da "Panoptikon, Superpanoptikon ve Sinoptikon iç içe geçmiştir" (Öztürk, 2013: 147-148). Ayrıca Truman'ın on sekizinci yüzyıl mahkumlarından temel farkı gözetlendiğinden haberdar olmamasıdır. Buna karşın bu durum, filmin herhangi bir epizodunda bir sorun olarak tanımlanmaz. Ana karakter için de durum farklı değildir. Truman gözetlendiğini fark ettiğinde öyküleme içindeki temel çatışması ne yeni bir boyuta girer, ne de bir düğümün oluşturucu öğesi olur. Finalde, programın yaratıcısı olan Christof ile diyalogunda yaşamının canlı yayınlandığını öğrendiğinde Truman'ın sorunu gözetlenmek ile değil, ilişkilerin gerçekliği ile ilgilidir. Christof, hayatı boyunca O'nu izlediğini, Truman'1 anladığını göstermek ve kalması için ikna etmek için söyler. Truman'ın bir hapis hayatı yaşadığına vurgu yapan Sylvia tarafından da, sürekli gözetlenmek etik bir sorun olarak dile getirilmez. Bu haliyle The Truman Show, panoptik sistemlerini yerküre düzeyine yaygınlaştırıp kimi durumlarda özneleri gözetlenme arzusuna kadar taşıyan biyo-iktidarın güncel konumu ile uyumlu bir hat çizer. Ne var ki filmin egemen iktisadi-politik retorikle asıl uyumu, bir taraftan temel meselelerini eleştirel bir konuma yerleştiriyor görünüp diğer taraftan kapitalizmin kurumsal dönüşümüne angaje oluşunda aranmalıdır.

\section{Egemenin Terk Ettiği Düzene Karşı Verilen Mücadele}

Akademik literatürde kapitalizmin, başta Batı toplumları olmak üzere Sanayi Dönemi paradigmalarını kökünden değiştiren bir dizi dönüşüm geçirdiğine dair sayısız çalışma karşımıza çıkar. Dönüşüme bir devrim niteliği atfeden egemen yaklaşım "Bilgi Toplumu", “Endüstri 4.0" gibi bir terminolojiyi popülerleştirirken, eleştirel ekonomi politik, yirminci yüzyılın son çeyreğinden itibaren etkilerini hissettirmeye başlayan bu dönüşümü finansallaşma, neoliberalizm, post-fordist örgütlenmeler, şirket egemenliği gibi kavramlaştırmalar yardımıyla çözümlemeye çalışır. Söz konusu dönüşüm hakkında söz alan Gilles Deleuze ise, Michel Foucault'nun çalışmasından hareketle disiplin toplumlarının yirminci yüzyılın ortalarında zirvesine ulaştıktan sonra çözülmeye başladıklarını belirtir (2013: 187). Foucault'nun terminolojisi ile söyleyecek olursak; biyo-iktidar, üzerinde egemenlik kurduğu toplumu kapatarak denetim altında tutmaktan vazgeçmeye başlar.

Kurumlarda gerçekleşen kapatma uygulamalarının vazgeçilmez olmadığını belirten Foucault, çağdaş kapitalizmin disiplin toplumlarından uzaklaştığını görmekteydi: “Altmışlı yıllardan itibaren, bu kadar zahmetli bir iktidarın sanıldığı kadar elzem olmadığının, sanayi toplumlarının beden üzerinde çok daha gevşek bir iktidarla yetinebileceğinin farkına varıldı" (Foucault, 2003: 41). Üretim paradigmalarında montaj hattını temsil eden fabrikanın yerine ürün odaklı ve modüler örgütlenen şirketi koyan kapitalizm, aynı zamanda kapatma kurumlarının da bir krize girmesine sebep olacaktır. The Truman Show filmi ise tam da bu krizin en keskin yönleriyle deneyimlendiği bir dönemde gösterime girecektir. Gilles Deleuze, Foucault'nun çalışmasından hareketle, disiplin toplumlarının krize girerek İkinci Dünya Savaşı'ndan sonra gerilediğini söyler: "bir disiplin toplumu, artık içinde olmadığımız, artık olmayı bıraktığımız şeydir" (Deleuze, 1992: 3). Deleuze, krizin ardından doğan yeni modeli "denetim toplumları" olarak adlandırmıştır: "Artık kapatıp-kuşatmayla değil, sürekli denetimle ve anlık işleyen iletişimle denetim toplumlarına girmekteyiz" (2013 :184). Bu yeni toplum, disiplin toplumlarının dönüşüme uğramasına sebep olmaktadır. 
Okul sürekli eğitime, hastaneler aile hekimliklerine, cezaevleri denetimli serbestliğe, fabrikalar ise şirketlere dönüşmektedir. "Artık okulda değilsin" ya da "artık işte değilsin" diyen muktedirin sesi yerini sürekli eğitime, tam zamanlı mesaiye bırakır. Sağlık ise bedeni düzenli aralıklarla tahlil edip hastalığı kontrol altında tutmayı amaçlar. Ceza yasaları uzun zamandır şartlı tahliye ve denetimli serbestliği etkin bir biçimde devreye sokmuş durumdadır. Foucault, disiplin toplumları analizini on sekizinci ve on dokuzuncu yüzyıl kapitalizmi ile bağlantılı olarak yapmaktaydı: "Bu toplumlar doruk noktalarına yirminci yüzyıl başlarında ulaşmışlardı" (Deleuze, 1992: 3). Okul, fabrika, hastane, hapishane gibi kapatma kurumlarında işletilen disiplinci rejim, yirminci yüzyılın ikinci yarısından itibaren Batı toplumlarında çözülmeye başlar. Gözlemlenen dönüşümün kurumsal ayağı, Richard Sennett'in Karakter Aşınması ve Yeni Kapitalizmin Kültürü kitaplarındaki görgül araştırmalarında ortaya çıkardığı gibi, bürokratik-hiyerarşik modelin yerini alan ă̆ biçimli esnek yatay örgütlenmelerdir:

"Şirketler bürokrasi katmanlarını azaltmaya, daha düz ve esnek organizasyonlar haline gelmeye uğraşıyor. Yönetimler organizasyonları, birer piramit şeklinde değil birer network olarak düşünüyor" (Sennett, 2008: 22). Bürokratik modelde kurumlar çalışanları ile uzun vadeli sözleşmeler yapar. Bir çalışan genellikle mesleki kariyerini bir kurumda tamamlar. Yöneticiler ve teknik elemanlar bu süreçte kendileri için öngörülmüş kariyer basamaklarını tırmanır. Buna karşın ağ tipi örgüt, birbirleri ile bağlantıll, kimisi kısa ömürlü, kimi daha uzun vadeli üretim adacıklarının organizasyonu anlamına gelir. Her bir adacık eklenip çıarılmaya uygun birer modül olarak iş görür. Kitlesel seri üretimin yerini proje bazlı üretim alır. Çalışanların kurum ile ilişkisi projenin ömrü ile belirlenir. Esnek uzmanlaşma, ağ örgütün mottosudur. Artık tırmanılacak bir kariyer merdiveni yoktur. Hiyerarşik diyagramın yerini takımlar, takım liderliği, "montaj hattının yerini, uzmanlaşmış üretim adacıkları almıştır” (Sennett, 2008, 53).

Bu kurumsal dönüşümler ve krizlerle ilişkili olarak incelendiğinde The Truman Show' un ana karakterinin temel çatışmasının, kapitalizmin uzaklaşmakta olduğu koşullar bütünü olduğu görülebilir. Amerikan ticari sinemasının bir ürünü olan The Truman Show, klasik anlatı kodlarını yeniden üreten türde bir öyküye sahiptir. Bu nedenle ana karakter, öyküsünün olay örgüsü içinde temel bir dügüüm ile karşılaşır. Karakterin çatışmalarını ve mücadelesini kuracak ve çözümüne ilerlemesini sağlayacak olan bu ana düğüm, aynı zamanda filmin genel temasının eleştirel konumunu da kurar. Truman kendisi için detaylarıyla tasarlanmış ve fiziksel olarak kapatılmış bir hayat yaşamaktadır. Öte yandan bu kapatılma onu kuşatan stüdyo mekândan ibaret değildir. Gündelik hayatının edimlerini belirleyip çeşitli rutinlere bağlayan kurumlar, asıl kapatılmayı ve bedeni üzerinde işleyen disiplin mekaniklerini oluşturur. Bu hayatın kendisinden habersiz biçimde canlı yayınlanması ise, temel düğümünün herhangi bir öğesine dahil değildir. Truman Burbank, başkalarının özendiği bir masa başı işe, ideal bir ev ve eşe sahip olmasına karşın gitmeyi, kendi sözleri ile "çımayı" (getting out) düşünür. Dünyayı görmek ve keşfetmek istediğini söyleyen Truman ile yaşayabileceği en iyi yerde olduğuna O'nu ikna etmek isteyen çevresi arasında karikatürize bir çatışma sürer. Burada karşımıza iki farklı karakterde Truman çıkar: Rutine binmiş ilişkilerinde jest ve mimikleri ile sahte bir parodi sergilerken, gitmek için harekete geçtiğinde daha sahici bir insana dönüşür. Katı bir rutinin içine hapsolan, evde olmanın güzellikleri üzerine televizyon filmlerine, seyahatin tehlikeleri üzerine acemice bir propagandaya sürekli maruz bırakılan Truman'ın ilk keşfedeceği hayatının düzmece olduğudur. Bu hayatı düzmece yapan asıl durum ise, Truman'ın içine yerleştirildiği kurumların artık işlemekte zorlanmasıdır. Ataerkilliği ve aileciliği ile bilinen Amerikan ticari 
sineması, The Truman Show özelinde bu özelliğini bir kenara bırakmıştır. Truman'ın babası bir travma kaynağı, annesi ise onu mekânda tutan bağken ve kurduğu aile dağılmakta iken, aile ve onun kutsallığı üzerinde herhangi bir değer yargısı üretilmez. Disiplin toplumlarının çekirdek kurumu olan aile bağlayıcı bir ethosla ilişkilendirilmez.

Truman'ın çatışması ve mücadelesinin temel ekseni de kendisini tutsak ederek denetimi altında tutacak olan bu kurumlardan kaçıp kurtulma arzusu üzerine kurulur. Bu nedenle en büyük duygusal yıkımını, onu kapatan stüdyonun sınırına vardığında, duvarları yumruklarken yaşar. Burası filmin ideolojik olarak bulunduğu tarafın açıkça ilan edildiği ve eleştirel boyutunun içeriğinin en net haliyle tanımlandığ ${ }_{1}$ sahnedir. Buna karşın bürokratik piramit modeline denk düşen ve Sanayi Dönemi paradigmaları içinde kalmış olan bu kurumlar halihazırda kapitalizmin geride bıraktığı ilişkiler toplamıdır. Egemenin yeni söylemi insanlardan sabit bir işe sadık değil, mobilize olmalarını; Truman örneğinde Fiji Adaları'na gitmelerini, üretken değil, girişimci olmalarını istemektedir. Truman'ın çatışmaya girdiği hayat tarzı, kapitalizmin artık üretmekten vazgeçtiği bir öznellik kipine denk düşmektedir.

\section{Dönüşümün İçindeki Kahramanın Öznelliği}

Kapitalist makinenin bu dönüşümü ile inşa edilen yeni kurumsal örgütlenme biçimlerinin ne olduğu ve hangi ideal öznenin üretilmeye çalışıldığı sorularının cevabı için ise The Truman Show doğru örnek değildir. Çünkü Truman, kapatılma ve disiplin kurumları ile girdiği mücadelesini kazandığında filmin temel düğümü de çözülmüş olur. Bu nedenle yeniye dair bu sorular, Truman'ın filmin finalinde çıktığı stüdyo kapısının diğer tarafında, dışında kalmıştır. Eğer yine bir film dolayımı ile Truman karakterini dışarıda bekleyen hayatın hangi koşulları sunduğu ve hangi tarzı olumladığını çözümlemek istersek Into The Wild filmini seçebiliriz. Çünkü her iki filmde de, ana karakterlerin reddettikleri üzerinden bir analoji kurmak mümkündür. Into The Wild filminin kahramanı Christopher ya da kendisine koyduğu isminle Alexander Supertramp da, tıpkı Truman gibi disiplin kurumları ile kuşatılmış bir hayata ve mesleki kariyere sırtını döner. Into The Wild, kapitalizmin yeni örgütlenmelerinin yanında üretmeye çalıştığı yeni öznellik modeli bakımından da incelemek için ideal bir filmdir. Söz konusu öznellik ise teorik çerçevesini ağırlıklı olarak neoliberalizm üzerine yürütülen çalışmalarda bulur.

Neoliberalizm, karakteristik özelliklerini öncelikli olarak özelleştirme, finansallaşma, deregülasyon gibi uygulamalar, işsizlik, güvencesiz ve k1sa vadeli istihdam, gelir adaletsizliğindeki artış, kamu hizmetleri, sosyal güvenceler, ücretlerdeki gerilemeler gibi semptomlarla gösterir. İlk bakışta bu durum kapitalist makinenin işleyişinin olağan bir sonucu olarak görünebilir. Sürecin güçlenmiş kapitalist biçimine şüphe duyulmamakla birlikte belli başlı uygulamaları ve sonuçlarıyla neoliberalizm bir dizi "yeni"yi beraberinde getirir. Susan George, yirminci yüzyılın ikinci yarısından önce toplumların günümüzün neoliberal uygulamalarına tümüyle yabancı olduğunu belirtir: "1945 ya da 1950 yılında, bugünün neoliberal paketiyle herhangi bir ciddi fikir ve politika teklifinde bulunmuş olsaydını, size gülüp geçerler ya da akıl hastanesine gönderirlerdi" (2009: 33). Eleştirel iktisadi yaklaşımlar neoliberal dönemeci genellikle finansallaşma kavramı ve borç krizleri ile birlikte ele alır. Gêrard Dumênil ve Dominique Lêvy, noliberalizmin egemenliğini sınıf çatışması ile ilişkilendirerek analiz eder. 1950'li ve 1960'lı yıllarda ücretli emeğin alım gücü, istihdam ve sosyal güvenlik sistemlerinde ilerlemeler kaydedildiğini, böylece sermayenin gelir ve haklarının gerilediğini 
vurgulayan Dumênil ve Lêvy, 1970'li ve 1980'li yıllarda bu sürecin yön değiştirdiğini belirtir: “Neoliberalizm ile birlikte, sermaye sahibi sınıflar üstün konumlarını, kapitalizm ise kendine has zorba gücünü yeniden ele geçirmiştir" (2009: 50). Dumênil ve Lêvy ekonomi ve toplumun kapitalist niteliklerinin yeniden inşa süreci olarak gördükleri bu evreyi "finansal kurumların ve sınıfların çatışması" (2009: 51) olarak tanımlar: "Bu yeniden inşa, finans adını verdiğimiz, melez bir toplumsal kimlik olgusudur ve kapitalist sinıfla finansal kurumların üst kesimlerini bir araya getirmektedir" (2009: 51).

Gelişmelerin ilk sonucu finans kapitalizminin egemenlik alanını genişletmesi olmuştur: “Firmanın tamamına finans mantığının sinmesi, üretim mantığı üzerine kurulu örgütlenme ve yönetim biçimlerini altüst ediyor" (Geuljac, 2013: 37). Böylece piyasa, arz talep terimleriyle kavranamaz hale gelerek, firmaların kendisini dahi "değeri günlük olarak ölçülen finansal bir ürün haline" (Geuljac, 2013: 37) getiren, hızlı ve anlık kazanç amacıyla kısa vadede sonuç bekleyen, "finans piyasalarının değişkenliğine emek piyasasının değişkenliği"ni (Geuljac, 2013: 38) dayatan bir kuvvet olarak ortaya çıar. Bu kuvvetler Sennett'in incelediği kurumsal dönüşümün de sebeplerinden birini oluşturur. Kısa vadede sonuç eklentisi, bürokratik modeli zayıflatan etkenlerden biridir. Anlık kazanç, gündelik bir ürün mantığı ilişkilerini de kısa vadeli kuran karmaşık ă̆ modeline evrilmeyi gerektirmiştir.

Bütün bu değerlendirmelerin yanında neoliberalizmin, özelleştirme ya da finansallaşma gibi iktisadi ve politik uygulamalardan ibaret bir uygulama olmadığını vurgulamak gerekir. $\mathrm{Bu}$ tam anlamıyla yeni bir akılsallık biçimi oluşturan bir yönetimsellik meselesidir ve neoliberal yönetim sanatında esas olan toplumu "standartlaştırmak ve disipline sokmak" (2015: 127) değildir. Söz konusu yeni akılsallık biçimi ortaya yeni bir özne kipini koyar. Tarihsel olarak yirminci yüzyılın son çeyreğinde kendisini açıkça göstermeye başlayan bu dönüşümün toplumun üyeleri üzerindeki farklarını, liberalizmin "üretken özne"si ve neoliberalizmin "girişimci özne"si biçiminde ayırt etmek mümkündür. Liberalizm, demokrasi ve kapitalizm ile "devredilemez haklara sahip yurttaş ile kendi çıkarı peşinde koşan ekonomik insan" (Dardot ve Laval, 2012: 363) biçiminde bölünmüş ancak ikinciye daha çok meyleden bir öznellik üretmişti. Liberal birey, gelenekler karşısında "tüm doğal yeteneklerinden yararlandığına, aklını ve iradesini serbestçe kullandığına" (Dardot ve Laval, 2012: 363) inanan özgürleşmiş bireydi. Ne var ki Dardot ve Laval, Marx'ın bu özgürlük veçhesinin altında "sermayenin değer kazanmasının kişisiz ve denetlenemez yasalarına köle olmanın yeni bir biçimi olduğunu" (2012: 363) gösterdiğini hatırlatır. Böylece özgürlüğünü ilan eden birey, "klasik siyasi iktisadın analiz etmeye başladığı büyük mekanizmaların çarkı olmaya devam edecektir" (2012: 363). Dardot ve Laval'ın modern bireyciliğin merkezi olarak nitelediği koşullar, "insan ilişkileri içinde genel bir sözleşmeli ilişki biçimi" ne (2012: 363) dönüşmüştür. Temel amacı, "hem hesapçı birey, hem de üretici emekçi olan insan"1 (2012: 364) ortaya koymak olan sözleşmeler, "daha önce hiç olmadı̆̆ı kadar insan ilişkilerinin ölçeği" (2012: 363364) haline gelirken, Bu kapsayıcı yönetim biçimi ise insanların "düşüncelerine kadar nüfuz eder, eşlik eder, yönlendirir, teşvik eder, eğitir" (2012: 364). Kapitalist ilişkilerin ürettiği özne yaygın olarak homo economicus biçiminde adlandırılır.

Burada homo economicus "birey ve iktidar arasında bağlantı noktası, birey üzerindeki iktidarın düzenleniş ilkesi" (2015: 209) olacaktır. Bu da homo economicusu yönetilebilir hale getiren bağlantıdır. İkincil olarak bu, ekonomik olmayan alanlara da uygulanabilir bir modeldir. Bunu olanaklı kılansa, ekonomik analizin nesnesinin "stratejik bir olanak, yol, araç 
seçimi içeren ve belli bir hedefi bulunan tüm davranışları" (2015: 220) kapsamasıdır. Yönetsel iktidarın mutlak denetim amacına ulaşmak için yalnızca ölçülebilir olana odaklanan pozitivist karakterini vurgulayan Gaulejac da, "homo economicus"a işaret eder: "Rasyonel davranışl1, araştırmacıların işini kolaylaştıran birey, bir homo economicus referans olarak alınıyor: bunun davranışlarını öngörmek, seçimlerini optimize etmek, onları hesap etmek ve varoluşunu programlamak mümkündür" (2013: 57-58).

Sanayi Dönemi'nin "üretken özne" si kapitalizmin en önemli çıtılarından biridir. Bu türden bir başarıya ulaşabilmek için çeşitli mekanizmalarla yalnızca maddi üretimi artırmaya çalışmanın yeterli olmayacağı açıktır. Her şeyden önce iktidar da kendisini, bağlı olduğu öznellikle birlikte bir üretici; yalnızca emek ürünü olarak değil, "yaşamının her alanında refah, mutluluk ve haz üreten özne" (Dardot ve Laval, 2012: 365) olarak konumlamalıdır. Bütün bunlara karşın Dardot ve Laval, asli amacı "uysallıkla çalışan, yararlı, tüketmeye hazır insanlar yaratmak, etkili insan yaratmak" (2012: 365) olan liberal faydacılığın, "öznenin içindeki çoğulluğu" (2012: 365) sona erdiremeyerek homojenleştirici ülküsüne ulaşmakta başarılı olamadığını belirtir. Buna karşın denetim toplumlarının tabi kılma mekanizmaları ile ortaya koyulan neoliberal yönetimselliğin yapılandırdığı öznellik için durum farklıdır. Bu yapılandırma şirket bünyesinde gerçekleşir, "üretken özne" yerine "girişimci özne" figürünü imal eder ve hepsinden önemlisi "öznelliğin çoğul biçimlerinde eşi görülmemiş bir birleşme gerçekleştirir" (2012: 366). Yeni özne, çalışkanlığı, görev insanı olması, daha büyük bir bütünün işlevsel uyumlu bir parçası olması ile değil; faaliyetine her şeyini vererek kendini adaması, tutkuyla bağlandığı işini arzulaması, sorumluluk ve riskten kaçmayarak hem aktif hem de kazanan bir şahıs olması ile ayırt edilir. Hedefe doğru atılan her adım, her tür kazanç, özne için aynı zamanda kendini gerçekleştirmenin bir biçimidir. Hiyerarşik konumunun, görev, sorumluluk ve haklarının bilincinde olan, uyumlu, yararlı özne miadını doldurmaktadır. Yeni-öznenin işi ve hayatı arasında bir ayrım kalmamalıdır. İş, arzuyu da kapsamalıdır.

Çağdaş kapitalizmin gerek öznellik üretim kipinde gerekse daha geniş kapsamlı yönetimsellik modellerinde deneyimlenen neoliberal dönüşüm, çeşitli krizlerle birlikte gerçekleşmiştir. Bunu liberalizmin içine düştüğü bir kriz olarak tanımlayan Dardot ve Lavall, bu krizin merkezine ise doğal hakları savunan mantık ile "fayda ilkesi" arasındaki çatışmayı yerleştirir (2012: 108). Faydacılığı esas alan bir yönetimsellik, haz peşinde ve acıdan kaçan bir varlık olarak tanımladığı insanın "arzularını üretken faaliyetlere yönlendirmeyi" (2012: 104) amaçlar. Hak ve fayda temelli anlayışlar arasındaki gerilim Dardot ve Laval tarafından liberalizmin krizi ile ilişkilendirilir. Hem söz konusu kriz, hem de neoliberal yönetimselliğin üretmeye çalıştığı öznellik kipi, Into The Wild filmini ana karakterinin serüveni ile ilişkili olarak değerlendirilebilir. Bu karşılıklı analiz, karakterin edimleri, benimsediği fikirler ve ulaştığı anafikirlerin yanında, aynı zamanda, benimsenen kurgu ekolü başta olmak üzere filmin sinematografik yaklaşımının çözümlemesine başvurularak da gerçekleşebilir.

Başta Hollywood olmak üzere anaakım sinema, çapraz kurgu, bir diğer adıyla paralel montaj adını alan ekolü benimser. Ticari Amerikan sineması tarafından geliştirilen ve D.W. Griffith' in en yüksek noktasına taşıdığı bu ekol, aynı zamanda sinema tarihinde geliştirilmiş diğer yaklaşımlardan farklı olarak günümüze kadar uygulanmaya devam etmiştir. Daniel Arijon'a göre, paralel montaj “bir ilgi merkezinden diğerine gidip gelinerek ilgili ya da karşıt öykü çizgilerinin açıklıkla ifade edilmelerinde" (1995: 19) kullanılır. Montajı bir organizma bir organik birlik olarak ele alan çapraz kurgu, birbirleri ile çatışmaya girecek farklılıklar 
barındırır. "Çeşitliliği oluşturan farklılaşmış parçalar iyi-kötü, zengin-yoksul, hırsız-polis, kadın-erkek gibi kutuplara ayrışırken montaj, biri diğerini takip edecek şekilde gerçekleşir" (İlic, 2017: 134). Bu yaklaşım stüdyo dilinde "o esnada başka bir yerde" biçiminde de özetlenir. Buna karşın blokların eş zamanlılığı bu kurgu anlayışının temel koşulu olmadığını sinemanın erken dönemlerinde bizzat Griffith tarafından gösterilmiştir. Birth of A Nation'da (Bir Ulusun Doğuşu, 1915) siyahlar ve beyazlar biçiminde ayrışan ögeleri eş zamanlı olarak kurgulayan Griffith, Intolerance'ta (Hoşgörüsüzlük, 1916) birbirinden farklı zamanlarda yaşanan dört adet olayı paralel almaşık biçimde montajlamıştır. Farklılıklar arasında gerçekleşen kesişim, çatışmayı oluştururken organizma tehdit altında kalır. Deleuze, tehdit altında olmanın organik birliğe has bir özellik olduğunu vurgular. Bir ev, bir, şehir, bir ülke ya da gezegen biçiminde tanımlanabilen bu organik birlik, anaakım sinemanın birçok örneğinde çatışmanın ardından yeniden tesis edilir. The Truman Show'da çapraz kurguya tabi kılınan iki temel blok, gitmek üzere harekete geçen Truman'ın eylemi ile program yapımcısının öznelliğinde somutlaşan stüdyodur. Finalde yoğunlaşan çatışma, Truman'ın fırtınalı denizdeki mücadelesine kadar ulaşırken, yapımcı ile iletişimsel karşılaşmasının ardından organik birlik olan programın ve fiziksel mekânı bir kapatma kurumu olan stüdyonun yeniden inşası değil, yıkımı gerçekleşir.

Into The Wild'da ise çapraz kurgulanan hareket-süre blokları, Alexander Supertramp'in filmin epizodik bölümlenmesinde "Magic Bus" olarak adlandırılan mekâna, Alaska'ya, vahşi doğaya ulaştığı anın ardından başlayan süre ile kendisine Supertramp ismini koyduktan sonraki yolculuğunun beş bölümlük serüvenidir. Bu serüven aynı zamanda geride kalan ailenin durumu ile kız kardeşin anlatısıyla kendi içinde çapraz kurgulanacaktır. Aynı zamanda filmin benimsediği ideolojik yaklaşımı anlamamıza yardım edecek olan bu ögeler, kahramanın içsel yolculuğundaki etik tartışmayı da açığa çıkarır. Kahramanın serüvenin başlangıcından önce, Supertramp'ın Alaska'ya varışı ve Christopher'ın kolejden mezuniyet süreci çapraz kurgulanmıştır. Böylece film, farklı iki hareket-süre bloğu ile başlar. Son derece katı, kız kardeşin stajyer sürücü belgesi ile araç kullanmasından, Christopher'ın sahneye koşarak gelmesini sorun edecek kadar, çocukları üzerinde ince ayrıntılarıyla disiplin süreçleri işleten otoriteryan biyolojik aile, bir taraftan çocuklarının geleceği üzerinde çeşitli onay mekânizmaları işletirken, diğer taraftan alıcısının isteklerini umursamayan, itirazını tartışma konusu eden hediye tercihleriyle narsisist bir portre çizer. Bu haliyle biyolojik aile, fertlerinin bedenleri üzerinde işleyen disiplin toplumlarının temel kurumlarından biri olur. Bunun yanında Christopher başından beri vurguladığı gibi sadece aileyi terk etmez. Harvard hukuk gibi bir kariyeri, yine bir Disiplin Toplumu bileşeni olan bir geleceği de reddetmiştir. Filmin "bilgelik çağı" adlı bölümünde yaşlı adama kestiği ahkâmda sarf ettiği "bence kariyer denen şey bir yirminci yüzyıl icadıdır" sözleri ile kast edilen, Truman'ın da savaşını verdiği, tam anlamıyla bürokratik hiyerarşik modelin kariyeridir.

"Kendi Doğumum" adını alan bölümle başlayan serüvende kahramanın kendisine yeni bir isim vererek Alexander Supertramp'a dönüşmesi, biyolojik aile ile de tüm bağların kopması anlamına gelecektir. Ancak kahramanın ailesizliği filmin ilerleyen bölümlerinde temel çatışmalardan biri olarak adım adım kurulur. Supertramp'ın "artık ailem yok" ilanına karşın Amerika, karşısına biyolojik aileyi ikame edecek seçenekler çıkarır. Karavanlarıyla

2Deleuze organizmayı "çeşitlilik içinde birliktir, yani birbirlerinden farklılaşmış parçaların bir kümesi" (2014: 48) biçiminde tanımlar. 
yersizyurdsuz ${ }^{3}$ bir hayat yaşayan hippi çift ile karşılaşmasının kendi doğumunun işlendiği bölümde gerçekleşmesi rastlantı değildir. Bu karşılaşma, çiftin kadın üyesi olan Jan'de bir sarsıntıya sebep olur. "Aile" adlı bölümde bu sarsıntının sebepleri ayrıntılarıyla açılanacaktır. Jan'in de Alexander gibi, O'nun yaşlarına yakın ve en önemlisi yuvayı terk etmiş bir oğlu vardır. Bir diğer seçenek ise, Alex'e evlat edinme teklifi eden yaşlı ve yalnız adam Ron Franz'dan gelecektir. Supertramp'ın biyolojik ailesini terk etmesi başlangıçta içinde yaşamak zorunda bırakıldığı katı otoriteryan rejime karşı bir davranış olarak tanımlanır. Bunun yanında hiçbir zaman resmen gerçekleşmemiş bir boşanma süreci yaşayan aile, çocuklarından gizlediği çeşitli sırlara da sahiptir. Bu nedenle karşımızdaki, sadece formel olarak bir arada duran, ancak aslında dağılmış bir ailedir. Buna karşın Supertramp'ın iletişimi tamamen kesmesi, film boyunca karakterin olumsuz yönü ve bir çelişkisi olarak kurulurken, finaldeki çözümün dinamiklerinden birini oluşturur.

Doğumun ardından gelecek olan "Gençlik" adlı ikinci bölüm paraya sırtını dönen Supertrump'ın ağırlıklı olarak yaşamını ve Alaska planının nasıl finanse ettiği ile ilgilidir. Bunun yanında Harvard' da hukuk okumayı reddeden kahramanın yolculuğunda çalıştığı işler, yeni kapitalizmin inşa etmekte olduğu kurumsal boyuta da denk düşmektedir. Kahramanın yolculuğunun bir parçası kılınan emek süreçleri, kapitalizmin dönüşümünün ardından karşımıza çıkan yeni paradigmalar için öne sürülen teorik tartışma ile birlikte okunabilir. Alexander Supertramp'ın film süresi içinde bir buğday ambarı ve bir hamburgerci olmak üzere iki işte çalıştığı görülür. Ancak hem Rainey ile sohbetinde hem de filmin öykülemesinin eksiltili doğası nedeniyle bu sayının daha fazla olduğu bellidir. Önceki işinden beklediği bir miktar para vardır. Gerekirse ikinci bir işte daha çalışabilir. Burada gösterilen ve sözü edilen işler yeni kurumsal örgütlenmelerin ruhuna tam olarak uygundur. Ucuzdur, güvencesizdir, kısa vadelidir ve vasıfsızdır. Sennett'in bulguladığ1 "uzun vade yok" (no long term) (2008: 23) şiarına uygundur. Bu, Guy Standing'in (2015) deyişiyle prekaryalaşma sürecinin de bir parçasıdır. ${ }^{4}$ Supertramp'ın annenin itici gücü ve babanın bilgi birikiminin birleşmesinden oluşan bir danışmanlık şirketi sahibi olan biyolojikailesini terk etmesi neoliberal yönetimselliğin uzlaşılarını tamamen reddetmesi anlamına gelmez. Bilakis Supertrump'ın öznelliğinin bileşenlerini oluşturan hedef odaklılığı kendisine bir meydan okuma zemini araması ve uzun vadeli ilişkilere karşı takınılan tutum neoliberalizmin mottoları ile uyumludur. Otoriteryan karakteri yumuşamış olan aileye imgesel geri dönüş, bu şirket-kurumun olumlanması anlamina gelecektir. Gençlik bölümünde ucuz, güvencesiz, kısa vadeli ve herhangi bir kariyer basamağının söz konusu olmadığı koşullarda çalışırken yaşantısından memnundur. O esnada çapraz kurgulanan diğer öge olan Alaska'da ise zirveden iniş sürecine girilir. Zayıflamaya; yiyecek bulmakta, temel gereksinimleri karşılamakta zorlanmaya başlar.

"Erkeklik" adını alan üçüncü bölümde hâkim olan, aile içi gerilim ve şiddet, geçmişle hesaplaşma gibi konulardır. Trende yaptığı kaçak yolculukta yakalanır. Yediği dayak, berduşluğun güvensizliğini ve risklerini ilk defa yüzüne vurur. Seyahatler, yeni geçici işler, otostopa durmayan araçlar, serüvenin tat vermeyen boyutunu ortaya çıkarır. Alaska'da ise,

\footnotetext{
${ }^{3}$ Gilles Deleuze, yersizyurdsuzlaşma terimini “kendi alanlarından koparılmış ve başka bir kavram içine yerleşmek zorunda kalmış olmak" (Parnet ve Deleuze, 1990: 35) biçiminde tanımlar.

${ }^{4}$ Standing'e göre, "geçici işlerde çalışmak durumunda olanlar prekarya içinde yer almaya yakındır çünkü sağlam olmayan üretim ilişkileri içerisindedirler” (2015: 33).
} 
başarısızlıkla sonuçlanacak olan bir geyik avı ve et kurutma deneyimi yaşanır. Gençliğin ardından gelen bu bölüm, bir olgunlaşma sürecine evrilmez. Alaska'daki Supertramp, baba figürünün etkisinden kendisini kurtaramamıştır. Geçmiş durmadan hatırlanır. Buna karşın, kız kardeşin anlatımıyla, ebeveynler Chris' in yokluğunun ardından değişir. Öfke, umutsuzluk ve suçluluk duyguları acıya dönüşürken; acı onları birbirine yakınlaştırmaya başlar. Yüz ifadeleri bile değişirken, şiddete dönüşen geçimsizlikler ortadan kalkar. Böylece Chris'in aileyi terk etmesini gerektiren sebepler belirsizleşmeye başlar. Supertramp'in erkeklik dönemi güçlenme ve olgunlaşmayı değil, yolunu karanlık ve çıkışsız bir labirente dönüştüren koşulları karşısına çıkarır.

$\mathrm{Bu}$ nedenle takip eden bölümlerin adlarının sırasıyla "Aile" ve "Bilgelik" olması rastlantı değildir. Alex için adım adım inşa edilen temel düğüm "Erkeklik" bölümünde kendi sınırına ulaşırken; "Aile" bölümü, finaldeki çözüm için ilk anahtarı kuracaktır. Erkekliğin çıkmazlarından kaçarak hippi çiftin yanına tekrar dönen Alex, Jan'in oğlunun da tıpkı kendisi gibi evi terk edip iletişimi tamamen kopardığını öğrenir. İnsan yapımı ve üzerinde "Tanrı Sevgidir" yazan Salvation Dağları çevresinde geçen bu bölümde, biyolojik ailenin yerine hippi ailesi ikame edilirken, yapay dağ ve etrafındaki ideolojik sosyal düzen birincil doğanın dağlarına karşı bir seçenek olarak koyulur. Vahşi hayatın içinde ise, Alex için temel bir kırılma ve dönüşüm anı gerçekleşecektir. Tolstoy'un Aile Mutluluğu adlı kitabından okuduğu "Çok şey yaşadım ve sanırım mutluluk için gerekli olan şeyi buldum. Kendilerine kolaylıkla iyilik yapılabilen ve buna alışkın olmayan insanlara faydalı olabileceğim bir yerde sakin ve münzevi bir hayat. Ve insanın faydalı olduğunu umabileceği bir iş" satırları kırılma anının başlangıcına işaret ederken bu süreç sinematografik olarak da çeşitli teknik ve efektlerle desteklenir. Kitabın satırları yakın planlarla taranırken "insanlar" (people) sözcüğ̈ü özellikle vurgulanır. Tolstoy'un metninde "ve sonra, tüm bunların üstünde, bir eş olarak sen ve belki de çocuklar. Bir erkeğin kalbi başka ne arzulayabilir ki" cümleleri okunurken, filme ilham veren gerçek Chris McCandless' in Alaska'da çekilmiş ve filmin sonunda da gösterilen fotoğrafı, giysiler, botlar, karakterin oturma şekli, kadraj, bir kısmı silinmiş yazısı ile otobüs, birebir taklit edilerek yeniden canlandırılır. Burası filmin öykülemesi ve sinematografisi içinde Aristoteles' in "baht dönüşü" (peripeteia) anıdır. ${ }^{5}$ Hedefine ulaşmış ve yalnız yaşamının tadını çıkaran Supertramp'ın aydınlanarak çelişkilerinin ve çatışmalarının çözülmesini ifade eder. Gerçek mutluluğun ne olduğunu fark eden Supertramp, terk ettiği hayata, bir işe yaramak, insanlara faydalı olmak adına geri dönmeye karar verir. Faydalı olma, faydalı olabilecek bir işe sahip olma üzerine kurulan kapitalist retorik, Supertramp'ın "bilgeliğinin" ilk adımlarını oluşturur. Taşan nehir geri dönüşe izin vermese de, mutluluğun sadece paylaşıldığında gerçek olduğunu anlayan kahraman, Christopher McCandless olan eski ismine geri döner. Yine Aristoteles'in Poetika'sından (2017) yararlanarak bu ismin öykünün dramatik akış1 içinde "tanınma" (anagnorisis) anı olduğunu söylemek gerekir . ${ }^{6}$ Alaska günlerinin başlangıç epizodunda, medeniyet tarafından daha fazla zehirlenmemek uğruna kaçtığını söyleyen Supertramp, doğa tarafından zehirlenir. Ölümünden hemen önce biyolojik ailesine bilinç düzeyinde kavuşacak, böylece çapraz kurgunun ögelerinin bu kesişim anı, anafikri, organik birliğin disiplin mekaniklerinden arınarak yeniden tesisi yönünde kuracaktır.

\footnotetext{
${ }^{5}$ Baht Dönüşü: “olan bitenin tam ters yöne doğru değişmesi” (Aristoteles, 2017: 41).

${ }^{6}$ Aristoteles tarafından "bilgisizlikten bilgiye geçiş" (2017: 41) şeklinde tanımlanan tanınma, anlatıda ağırlıklı olarak bir karakterin tanınması, kim olduğunun anlaşılması biçiminde uygulanır.
} 
"Magic Bus" adını alan vahşi hayat süreci ile Supartramp'ın beş epizotluk serüveninin çapraz kurgusu, karakterin içsel çelişki ve çatışmalarını ortaya koyarken, ögeler arasındaki kesişim yine çapraz kurgunun temel özelliklerinden biri olan bir düelloya döner. Gerçekliği paylaşımda bulan Supertramp, bu düellonun sonunda vahşi yaşamı terk etmeye ve insanların içine dönmeye karar verecektir. Bu noktada fayda ilkesini hatırlar ve filmin öyküsündeki baht dönüşüne sebep olan faydalı olma ile ilgili satırlar ile ilişkilendirirsek, karakterin sonunda ulaştığ1 ana fikrin egemen ideolojilerle uyumlu olduğunu görürüz. Esasen Supertramp, bütün yönleri ile neoliberal bir girişimci öznellik modeline geri dönmez; ancak geri döndüğü dünyanın istikameti de bu yöndedir. İmgesel olarak kavuştuğu ailenin bir şirket sahibi olması önemli bir veridir. Supertramp daha çok bu öznelliğin şafağına, fayda ilkesi ile boğuşan ve neoliberal öznelliğin doğacağı liberal krize doğru adımlar. Disiplin toplumları asayiş adında kapattığı bireyleri zorla çalıştırıyordu; yeni toplumda ise çalışmak, tıpkı Supertramp'ın yaşadığı aydınlanmada olduğu gibi arzulanmalı, etik olarak tercih edilmelidir. Büyük kazançları, hiyerarşik kariyeri ve unvanları reddetse bile yararlı bir işte çalışmak, her durumda homo-economicus öznelliğinin tanımlandığı bölgelerden biridir.Supertramp'ın homo-economicusun dişına çıktığı tek zaman-mekân blogu olan Alaska, çapraz kurgunun düellosunun kaybedenidir.

\section{Sonuç}

The Truman Show ve Into The Wild filmleri, Batı'da disiplin toplumları ile getirilen iktidar dispozitiflerinin çözülüşü ile gerçekleşen dönüşüm bağlaminda incelenebilir. Bir kapatma kurumundan çıkma mücadelesi veren ve otoriteryan ailesinden uzaklaşan karakterlerin yaşamlarına dair analiz, kapitalist dönüşümün ideolojik ve etik konumlanmasını somutlaştırmak açısından da önemlidir. Kapatma kurumlarından ve bu kurumların öznellikler üzerine kurduğu otoriteryan disiplinci ilişkisellikten uzaklaşan karakterler, iki filmi birbiri ile semantik olarak bağlar. Gözetlendiğinden habersiz olması ile herhangi bir meselesi olmayan Truman'ın kazandığı mücadelenin ardından çıktığı yer, Chris'in sürekli seyahat halindeki yersizyurdsuz yaşamıdır. Bu yaşam aynı zamanda dışarıya başarılı görünen, ancak sırlar ve şiddet içeren kapalı bir kurumsal yapılanmaya da karşı çıkar. Kariyeri eleştiren Chris'in reddettiği, bürokratik hiyerarşik piramit biçimli örgüt modelidir. Into The Wild filminde "vahşi hayat" ile "yolculuk" olarak tanımlayabileceğimiz iki ana ögenin çatışma ve kesişiminin sonucunda benimsenen etik, yalnızlık karşıtıdır. Uygarlığın herhangi bir boyutunu içermeyen bir zaman-mekân, çapraz kurgunun olumsuz ögesidir. Chris, deri işlemeye, hamburgerciye, tahıl ambarı işçiliğine, faydalı olduğu yere, şirket sahibi ailesine, değilse yeni ailesine, onu evlat edinmeye hazır büyükbabasına geri dönmelidir. Fayda, tam da Dardot ve Lavall'ın gösterdiği gibi, neoliberal akılsallığa doğru giden yolun dönemeçlerinden biridir. Burası piyasa ekonomisinin yasaları ile mantığının işlediği bölgedir. Kapatma kurumlarına karşı verilen mücadele, kapitalizmin halihazırda terk etmeye başladığı model olduğu ve piyasa ekonomisinin elinin uzanamadığı mutlak yalnızlık ve birincil doğa deneyimlerinin yerine yararlı bir iş sahibi olma sloganı benimsendiği için, The Truman Show ve Into The Wild filmlerinde kahramanların mücadeleleri ile şekillenen eleştirellik sahtedir. 


\section{Kaynakça}

Arijon, Daniel, (1995). Film Dilinin Grameri 1, Y. Demir, N. Bayram, U. Demiray, N. Ulutak, M. Barkan (çev.), İstanbul: Kavram.

Aristoteles, (2017). Poetika, Nazile Kalaycı (çev.), Ankara: Pharmakon.

Dardot, P. ve Laval, C. (2012). Dünyanın Yani Aklı, Iş1k Ergüden (çev.), İstanbul: İstanbul Bilgi Üniversitesi Yayınları.

Deleuze, Gilles, (1992). "Postscript on the Societies of Control”, October, (59), 3-7.

Deleuze, Gilles, (2013). Müzakereler, İnci Uysal (çev.), İstanbul: Norgunk.

Deleuze, Gilles, (2014). Sinema 1 - Hareket-İmge, Soner Özdemir (çev.), İstanbul: Norgunk.

Dumenil, G. ve Levy, D. (2009). "Marksist Bir Neoliberalizm Teorisi”, Neoliberal İktisadın Marksist Eleştirisi, Hilmi Tunalı (çev.), İstanbul: Kalkedon.

Feldman, E. S. (Yapımc1), Weir, P. (Yönetmen). (1998). The Truman Show [Sinema Filmi]. ABD: Paramount Pictures.

Foucault, Michel, (2000). Hapishanenin Doğuşu, Mehmet Ali K1lıçbay (çev.), Ankara: İmge.

Foucault, Michel, (2003). İktidarın Gözü, Işık Ergüden (çev.), Ankara: İmge.

Foucault, Michel, (2005). Entelektüelin Siyasi İşlevi, Ferda Keskin (çev.), İstanbul: Ayrıntı.

Foucault, Michel, (2010). Cinselliğin Tarihi, Hülya Uğur Tanröver (çev.), İstanbul: Ayrintı.

Foucault, Michel, (2015). Biyopolitikanın Doğuşu, Alican Tayla (çev.), İstanbul: İstanbul Bilgi Üniversitesi Yayınları.

Gaulejac, Vincent, (2013). İşletme Hastahı̆ına Tutulmuş Toplum, Özge Erbek (çev.), İstanbul: Ayrıntı.

George, Susan, (2009). “Neoliberalizmin Kısa Tarihi”, Gülsüm Akalın (çev.), Neoliberal İktisadın Marksist Eleştirisi, İstanbul: Kalkedon.

İlic, Erdem, (2017). Film Atölyesi: Sinemanın İmgelem Araçlarn, Ankara: Pharmakon.

Parnet, C. ve Deleuze, G., (1990), Diyaloglar, Ali Akay (çev.), İstanbul: Bağlam Yayınları.

Penn, S. (Yapımc1), Penn, S. (Yönetmen). (2007). Into The Wild [Sinema Filmi]. ABD: Paramount Vantage.

Peters, Thomas, A., (1999). Computerized Monitoring and Online Privacy, N.Carolina: McFarland \& Company.

Poster, Mark, (1990). The Mode of Information, New York: Free Press.

Sennett, Richard, (2008). Karakter Aşınması, Barış Yıldırım (çev.), İstanbul: Ayrıntı.

Standing, Guy, (2015). Prekarya, Ergin Bulut (çev.), İstanbul: İletişim. 